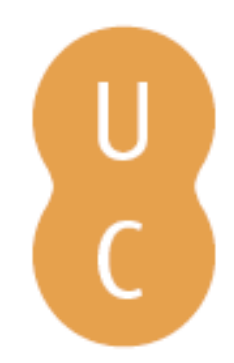

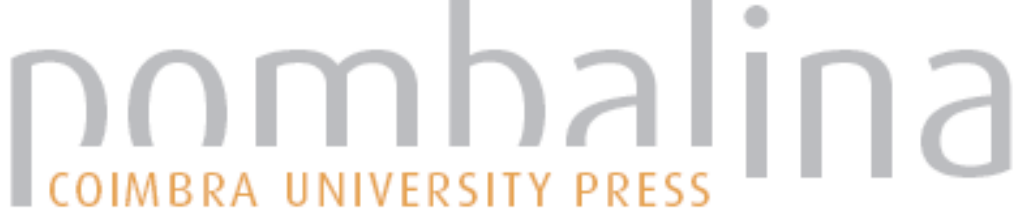

\section{An experimental approach to the evaluation of prescribed fire behavior}
Autor(es):
Mueller, Eric; Skowronski, Nicholas; Clark, Kenneth; Kremens, Robert; Gallagher, Michael; Thomas, Jan; El Houssamia, Mohamad; Filkov, Alexander; Butler, Bret; Hom, John; Mell, William; Simeoni, Albert

Publicado por: Imprensa da Universidade de Coimbra

URL persistente:

URI:http://hdl.handle.net/10316.2/34021

DOI:

DOI:http://dx.doi.org/10.14195/978-989-26-0884-6_4

Accessed : $\quad$ 26-Apr-2023 12:49:47

A navegação consulta e descarregamento dos títulos inseridos nas Bibliotecas Digitais UC Digitalis, UC Pombalina e UC Impactum, pressupõem a aceitação plena e sem reservas dos Termos e Condições de Uso destas Bibliotecas Digitais, disponíveis em https://digitalis.uc.pt/pt-pt/termos.

Conforme exposto nos referidos Termos e Condições de Uso, o descarregamento de títulos de acesso restrito requer uma licença válida de autorização devendo o utilizador aceder ao(s) documento(s) a partir de um endereço de IP da instituição detentora da supramencionada licença.

Ao utilizador é apenas permitido o descarregamento para uso pessoal, pelo que o emprego do(s) título(s) descarregado(s) para outro fim, designadamente comercial, carece de autorização do respetivo autor ou editor da obra.

Na medida em que todas as obras da UC Digitalis se encontram protegidas pelo Código do Direito de Autor e Direitos Conexos e demais legislação aplicável, toda a cópia, parcial ou total, deste documento, nos casos em que é legalmente admitida, deverá conter ou fazer-se acompanhar por este aviso.

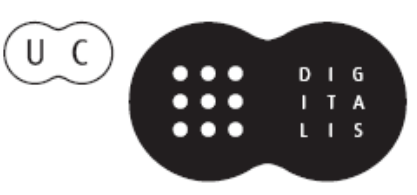




\section{ADVANCES IN}

Forest Fire

\section{RESEARCH}

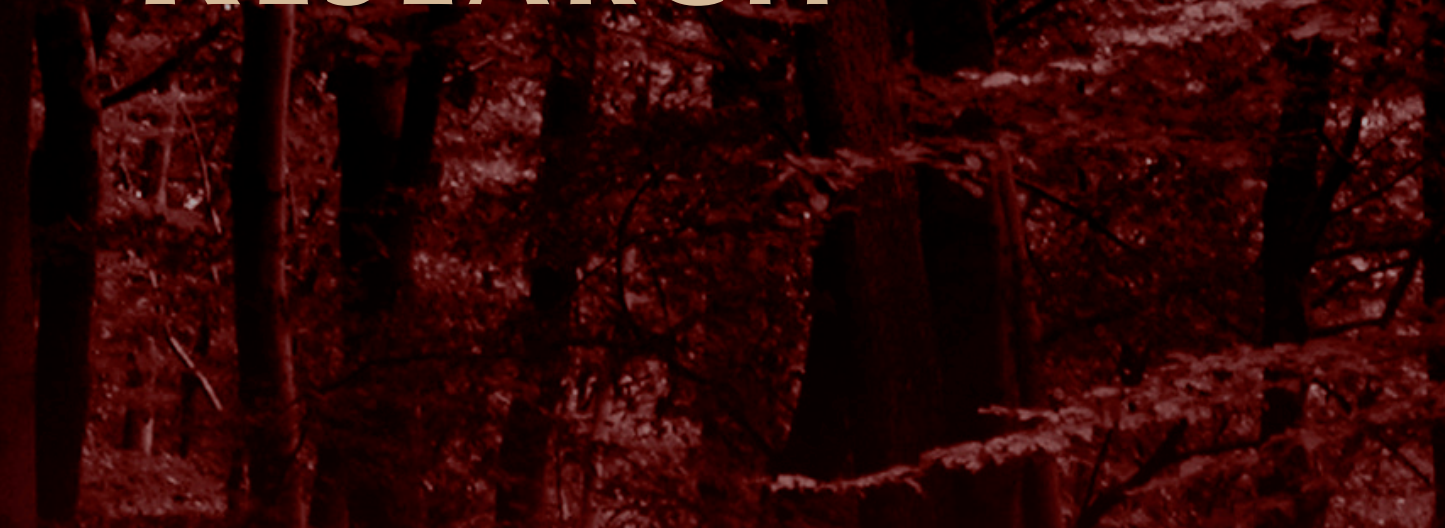

\section{DOMINGOS XAVIER VIEGAS}

\section{EDITOR}




\title{
An Experimental Approach to the Evaluation of Prescribed Fire Behavior
}

\author{
Eric Mueller ${ }^{\mathrm{a}}$, Nicholas Skowronski ${ }^{\mathrm{b}}$, Kenneth Clark ${ }^{\mathrm{b}}$, Robert Kremens ${ }^{\mathrm{c}}$, Michael Gallagher ${ }^{\mathrm{b}}$, Jan \\ Thomas $^{\mathrm{a}}$, Mohamad El Houssamia ${ }^{\mathrm{a}}$, Alexander Filkov ${ }^{\mathrm{d}}$, Bret Butler ${ }^{\mathrm{e}}$, John Homª, William Mellf, and \\ Albert Simeoni ${ }^{\mathrm{a}}$ \\ ${ }^{a}$ University of Edinburgh, BRE Centre for Fire Safety Engineering, Edinburgh, UK, \\ e.mueller@ed.ac.uk \\ ${ }^{b}$ USDA Forest Service, Northern Research Station, Morgantown, WV, New Lisbon, NJ and Newtown \\ Square, PA, USA \\ ${ }^{c}$ Rochester Institute of Technology, Center for Imaging Science, 54 Lomb Memorial Drive, \\ Rochester, NY 14623, USA \\ ${ }^{d}$ National Research Tomsk State University, Department of Physical and Computational Mechanics, \\ Russia \\ ${ }^{e}$ USDA Forest Service, Rocky Mountain Research Station 5775 W US Highway 10 Missoula MT \\ 59808, USA \\ ${ }^{f}$ USDA Forest Service, Pacific Wildland Fire Sciences Laboratory, 400 N 34th St., Suite 201, \\ Seattle, WA 98103, USA
}

\begin{abstract}
Prescribed fire is a commonly used practice for managing wildland fire spread and intensity. However, due to limits in the current scientific understanding of wildland fire behavior in general, it is difficult to predict the effectiveness and efficiency of a particular regimen of prescribed fire-based fuel treatments in a given environment. As part of a larger project intended to aid in such an assessment, the first in a series of experimental prescribed fires was conducted. Efforts were made to both quantify various aspects of fire behavior and to obtain an accurate measure of pre- and post-fire fuel loadings. This paper focuses on an initial investigation of the fire behavior, as this is necessary for contextualizing the level of fuel treatment achieved. In particular, the range of observed surface fuel consumption and fireline intensities is discussed, the role of ambient wind conditions is considered, and a qualitative assessment of canopy fuel consumption is presented.
\end{abstract}

Keywords: Fire behavior, prescribed fire, fuel treatments, fire intensity

\section{Introduction}

Hazardous fuel reduction treatments are important for both the mitigation of wildland fire risk and the support of suppression efforts. In the United States, significant financial resources have been directed to this goal, with an average of $\$ 500$ million spent by the Federal Government each year from 20022012 (Gorte 2011). However, rigorous experimental measurement and proper metrics to measure the success of fuel reduction measures are lacking. As stated by Omi and Martinson (2002), "the lack of empirical assessment of fuel treatment performance has become conspicuous". While the aforementioned report found that fuel treatments were able to modify extreme fuel behavior, questions remain as to the intensity and repetition of treatment needed in a given ecosystem to maintain a desired condition. Further, the success of a certain treatment may not be consistent for different ecosystems or treatment techniques (Gorte 2011). More work is clearly needed to understand and evaluate the effectiveness of these types of treatments.

One technique used to accomplish the reduction of hazardous fuels is prescribed fire, and is the focus of this work. When attempting to develop efficient and effective fire-based fuel treatment strategies, a proper understanding of fire behavior is particularly important. Managers must be able to understand 
how a prescribed fire will behave, given a particular set of conditions, as well as predict the subsequent impact on fuel loading. In an effort to improve this understanding, a Joint Fire Science Program (JFSP) funded project is being conducted. This project takes a dual experimental and numerical approach. It aims to use a series of well-instrumented prescribed fires as a source of direct measurements, which can both provide a quantitative analysis of fire behavior and fuel reduction, as well as comparison criteria for use in the development of physical fire behavior models. Such models have the potential to be effective tools for the continued investigation of both general fire behavior and specific topics, such as fuel treatment effectiveness, without requiring extensive experimentation.

The work here pertains specifically to the first of the experimental prescribed fires. The measurement of wildland fire behavior properties is not a novel concept, as can be seen in experiments like those of Santoni et al. (2006), Viegas et al. (2006), Morandini and Silvani (2010), and Frankman et al. (2013). However, the number of such experiments is limited, and each is specific to a particular set of conditions. This work will help to strengthen the scientific understanding of fire behavior by adding to the collection of available measurements. Additionally, due to the focus on fuel reduction, the detail to which pre-fire fuel loading, fire behavior, and post-fire fuel loading are studied and can be correlated is rather unique. This experiment was also designed from the outset so that measurements would be both easily translatable to model inputs and comparable to model outputs.

Though a variety of different measurements were taken, the results analyzed in this paper represent an initial effort to describe the history of the fire spread and its general characteristics. Focus is put on estimates of fireline intensity, the role of ambient wind conditions, and basic characteristics of canopy fuel consumption.

\section{Methods}

\subsection{Study site}

The experimental fire was conducted in the Pinelands National Reserve (PNR) of New Jersey, United States. The PNR spans approximately 445,000 ha, and is the site of an active fuel management program by the New Jersey Forest Fire Service (NJFFS) and federal wildland fire managers. Prescribed fires are employed by the NJFFS with the explicit intent of reducing fuel loads and thus mitigating fire risk. These managers, for the most part, rely on professional judgment when planning the intervals and geographic position of these fires. The climate is classified as cool temperate, with mean monthly temperatures of 0.3 in January and $24.3{ }^{\circ} \mathrm{C}$ in July, and mean annual precipitation is $1159 \mathrm{~mm}$. The terrain consists of plains, low-angle slopes, and wetlands, with a maximum elevation of $62.5 \mathrm{~m}$. A burn block covering an area of 16.6 acres was used for the experiment, and can be seen outlined in Figure 1. The forest canopy in the block was comprised primarily of Pitch Pine (Pinus rigida Mill.), with intermittent oaks (Quercus spp.). The understory contained a mixed shrub layer of huckleberry (Gaylussacia spp.), blueberry (Vaccinium spp.), and scrub oaks (Quercus spp.). The perimeter of the block was comprised of access roads, with a narrower track running through the center of the block. These were created to facilitate access for the management of prior prescribed burns.

\subsection{Measurement techniques}

Point measurements of fire behavior were made using a combination of 4 overstory towers, 12 understory towers, and 3 Fire Behavior Packages (FBP), each supporting various instruments. Each overstory tower provided measurements of turbulence (3D sonic anemometer) at a height of 12.5 meters, and a vertical array of air temperature (8 K-type thermocouples) at even $1.5 \mathrm{~m}$ intervals from 0.5 to 11.0 meters. Dataloggers were buried in waterproof boxes and a sampling rate of $10 \mathrm{~Hz}$ was used. Each understory tower provided measurements of upward radiative flux (downward facing radiometer) at a height of 6.0 meters, vertical velocity (bi-directional pressure probe) at a height of 6.0 
meters, and a vertical array of temperature ( $5 \mathrm{~K}$-type thermocouples) at even $1.5 \mathrm{~m}$ intervals from 0 to 6.0 meters.

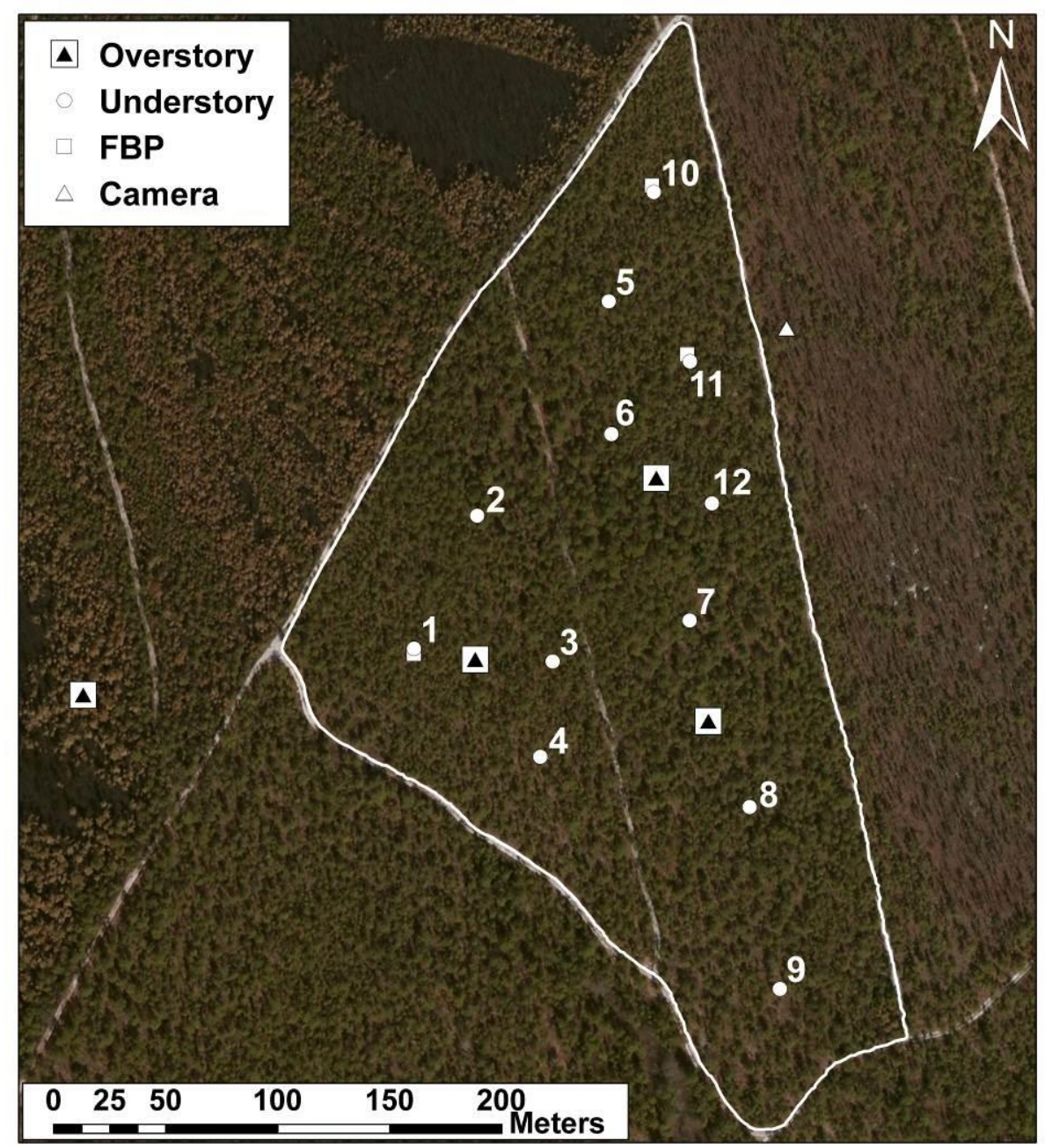

Figure 1. Layout of instrumentation in the study site with understory tower numbers labeled.

Dataloggers were located in protective enclosures at the top of the towers and a sampling rate of 0.5 $\mathrm{Hz}$ was used. Each FBP provided measurements of total and radiative incident heat flux (dual radiometer), horizontal and vertical velocity ( 2 bi-directional pressure probes), and temperature (Ktype thermocouple), all at a height of roughly 1 meter (Butler et al. 2010). Dataloggers were housed in a protective enclosure and a sampling rate of $10 \mathrm{~Hz}$ was used. All instruments were distributed within the area to be burned, excluding one overstory tower, which was situated to the west in order to measure ambient conditions during the time of the fire. Exact instrument locations can be seen in Figure 1. In addition to point measurements, sequential aerial IR images of the fire were recorded from an aircraft using Rochester Institute of Technology's Wildfire Airborne Sensor Program (WASP) (McKeown et al. 2011). The WASP records data in short-wave $(1.0-1.7 \mu \mathrm{m})$, mid-wave $(3.0-5.0 \mu \mathrm{m})$, and long-wave $(8.0-9.2 \mu \mathrm{m})$ infrared spectral bands, as well as the visible spectrum $(0.4-0.9 \mu \mathrm{m})$. Images were time-stamped and georeferenced. Of the above instrumentation, this paper only discusses measurements obtained with the sonic anemometers and the aerial IR camera. As a visual reference, several cameras were placed within and around the burn block. The camera discussed here was placed outside of the site, looking east towards Understory 11 at a distance of about 45 meters.

Field measurements of surface fuel loading were obtained by destructive sampling of the forest floor and shrub layer in $1 \mathrm{~m}^{2}$ clip plots. 36 of these measurements were made ( 3 surrounding each understory 
tower) both pre- and post-fire, in order to give an indication of surface fuel consumption. Measurements from the litter layer $\left(\mathrm{O}_{\mathrm{i}}\right.$ horizon) were divided into categories of fine fuel, reproductive material (pine cones, acorns, and catkins), 1-hr wood, 10-hr wood, and 100-hr wood, while measurements from the shrub and oak layer fuels were divided into categories of foliage, 1-hr wood and 10-hr wood. It should be noted that a destructive sampling technique inherently excludes colocation of pre- and post-fire measurements. Remote measurements of both pre- and post-fire canopy fuel loading were conducted using an airborne Light Detection and Ranging (LiDAR) technique. This data will allow the generation of a $1 \mathrm{~m}$ x $1 \mathrm{~m}$ resolution canopy height model, as well as 3D canopy bulk density (CBD) profile at a resolution of $10 \mathrm{~m} \times 10 \mathrm{~m} \times 1 \mathrm{~m}$. CBD will be calibrated to profiles from an upward-sensing LiDAR unit in twelve $20 \mathrm{~m}$ x $20 \mathrm{~m}$ plots within the burn area. This unit has been previously calibrated to represent profiles of CBD using equations developed through destructive harvest by Clark et al. (2013). As this calibration is currently ongoing, only a qualitative discussion of the relative reduction in canopy fuel loading will be given.

\subsection{Measurement techniques}

In order to characterize the type of fire observed, it is useful to estimate the quantity known as fireline intensity $(I)$, which indicates the energy release rate per unit length of fire front (Byram 1959). Fireline instensity is often calculated as $I=H \cdot \Delta m \cdot R$, where $R$ is the rate of spread $\left[\mathrm{m} \cdot \mathrm{s}^{-1}\right], \Delta m$ is the mass of fuel consumed [kg], and $H$ is the heat yield of the fuel. In this study, $H$ is taken as $18700 \mathrm{~kJ}^{-\mathrm{kg}^{-1}}$ (Alexander 1982). This value of $H$ is the low heat of combustion and is an estimate based on an average value for a number of different fuel species. However, studies have shown that the typical variation between species is only on the order of $\pm 10 \%$ (Byram 1959, Van Wagner 1972). Corrections may also be considered to account for completeness of combustion and mass consumption during smouldering combustion, after the fire front passage, but for the purposes of the study this basic value is sufficient. As canopy fuel consumption estimates are not yet available, only the physical measurements of surface fuel consumption were used. Thus, the quantity will be referred to as surface fireline intensity $\left(I_{\text {surf }}\right)$. Finally, due to the inability to collocate pre- and post-fire physical fuel samples, as mentioned in Section 2.2, consumption estimates for larger fuel elements were considered unreliable, as they were sparsely distributed. For example, 100-hr fuel will likely not be completely consumed, but if no such fuel is located in the post-fire sample plot before the fire, calculation of the difference would suggest that total mass in the pre-fire plot was consumed. Therefore, only fine fuel (primarily needle litter), 1$\mathrm{hr}$ forest floor wood, and 1-hr oak and shrub layer material was used to calculate $I_{\text {surf }}$. Further, thin fuel was considered to be the main contributor to fire intensity. Spread rates were obtained from the aerial IR imagery.

\subsection{Burn conditions}

The fire was conducted on March $5^{\text {th }}, 2013$. Ignition was carried out by the NJFFS using a drip torch along the northwest road, moving from northeast to southwest over a roughly 8 minute period, starting at 11:53 (EST). The real-time location of the drip torch on this road was tracked by GPS. Due to safety concerns caused by rapid fire growth, a secondary ignition line was subsequently created along the southwest road. The duration of the fire was determined to be approximately 1 hour, though much of the block was consumed within the first 20 minutes. During this 1 hour period, mean ambient temperature was around $7{ }^{\circ} \mathrm{C}$ and mean relative humidity was $39 \%$. Fuel moisture content (FMC) was measured for different classes of vegetation during the burn, details of which can be seen in Table 1 . Samples were taken from the stand immediately to the north of the burn block. 
Table 1. Measurements of fuel moisture content (FMC \pm relative standard deviation) for fuel collected during the time of the fire.

\begin{tabular}{|c|c|c|c|}
\hline Location & Fuel Type & Sample size & FMC [\%] \\
\hline \multirow{2}{*}{$\begin{array}{l}\text { Canopy } \\
\text { Pine) }\end{array}$} & Live needles & 7 & $114.4 \pm 2 \%$ \\
\hline & Live stems (1-hr) & 7 & $85.2 \pm 8 \%$ \\
\hline \multirow[t]{2}{*}{ Understory } & Shrub stems (1-hr) & 8 & $60.9 \pm 9 \%$ \\
\hline & Oak stems (1-hr) & 5 & $61.2 \pm 12 \%$ \\
\hline \multirow[t]{4}{*}{ Forest Floor } & 1-hr wood & 7 & $15.3 \pm 16 \%$ \\
\hline & 10-hr wood & 10 & $30.9 \pm 52 \%$ \\
\hline & Needle litter & 8 & $22.5 \pm 50 \%$ \\
\hline & Oak leaf litter & 7 & $15.7 \pm 45 \%$ \\
\hline
\end{tabular}

\section{Results}

\subsection{General fire spread}

Between the time of 11:56:59 (EST) and 12:38:45 (EST), 16 IR images were captured by the WASP as the plane made passes overhead and allowed the mapping of fire progression (Figure 2). The contours displayed in Figure 2 were obtained by tracing along the sharpest gradient of pixel intensity recorded for each long-wave image. Only 7 of the 16 contours are shown, as these represent the fire behavior of interest for this study. These will be referred to as P2-P8 hereinafter.

The primary fire front, originating from the northwest road, spread as a head fire in a southeasterly direction. It did not completely merge with the secondary (backing) fire front until sometime between fire contour P5 and P6. At certain locations the fire contours sharply dips back to a point which appears to lag behind in the direction of spread (Figure 2). In many places, this feature can be attributed to the narrow track which ran along the center of the block, as can be seen in Figure 1. This track acted functioned as a fuel break, because the only fuel consisted of a thin and intermittent litter layer. However, the resulting discontinuities in the fire front coalesced with continued fire spread, as can be seen when comparing contour P5 to P6 in Figure 2. Other irregular features of the fire contours, such as along the west portion of $\mathrm{P} 3$, may be due to fuel heterogeneity, discontinuity in the ignition line, or some combination of the two.

\subsection{Local surface fire intensity}

Given that each understory tower was surrounded by 3 mass consumption field sample plots, and fire contours were available across the entire burn block, it was possible to calculate local surface fireline intensity to get an indication of the range of fire behavior. A selection of locations are shown in this report, which are, moving from north to south, understory towers $10,5,11$, and 1 . These were chosen as initial sites to investigate as they were situated in a region of headfire which was unaffected by the backfire. Spread rates at each of these locations were determined by measuring distances between fire contours in ArcGIS. Each distance was measured 15 times along a segment of around 60 meters of fire front in order to both minimize measurement uncertainty and to give a general indication of the relative homogeneity of local fire spread. A summary of the calculations for each location, resulting in surface fireline intensity, is presented in Table 2.

At the location of Understory 10, near the northern corner of the plot and the start of the ignition line, the lowest intensities were found (of the locations considered). Estimated values fall between 500$1300 \mathrm{~kW} \cdot \mathrm{m}^{-1}$. This was a result of both low mass consumption and slow fire spread, as can be seen in Table 2. 


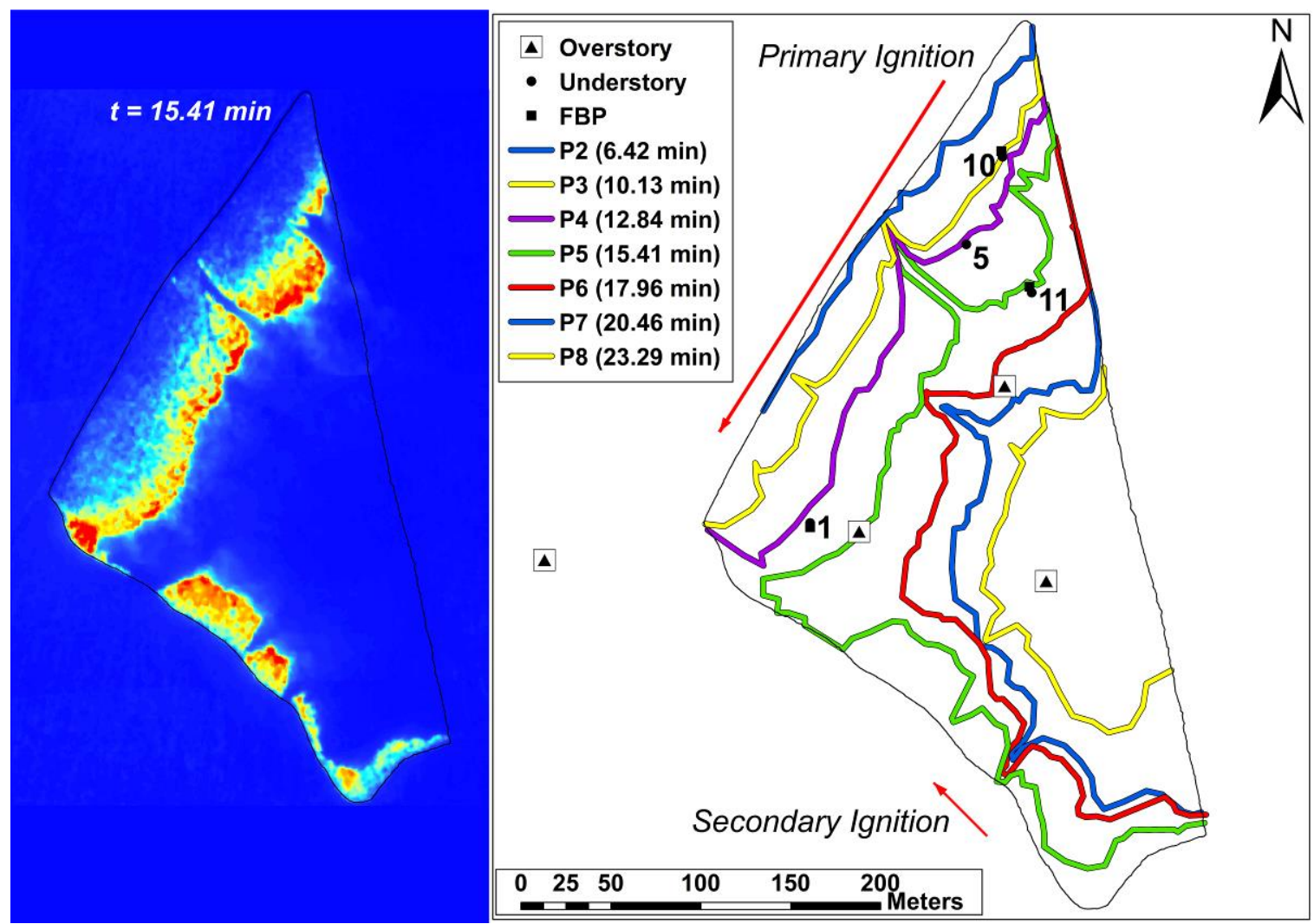

Figure 2. (Left) Example IR image from the WASP (P5). (Right) Progression of the fire front, extracted from IR imagery. The fire progressed from West to East, with consecutive fire contours labeled P2-P8. The time of each contour is given in minutes after the start of ignition.

Table 2. Summary of $\Delta m$ ( \pm maximum relative difference in the 3 samples), $R$ ( \pm relative standard deviation), and $I_{\text {surf. }}$ Values of $I_{\text {surf }}$ are rounded to the nearest $100 \mathrm{~kW} \cdot \mathrm{m}^{-1}$

\begin{tabular}{lllll} 
Location & $\Delta m\left[\mathrm{~kg} \cdot \mathrm{m}^{-2}\right]$ & Distance & $R\left[\mathrm{~m} \cdot \mathrm{s}^{-1}\right]$ & $I_{\text {surf }}\left[\mathrm{kW} \cdot \mathrm{m}^{-1}\right]$ \\
\hline Understory & $0.73 \pm 41 \%$ & P2-P3 & $0.095 \pm 7 \%$ & $1300 \pm 52 \%$ \\
10 & & & & \\
& & P2-P4 & $0.074 \pm 10 \%$ & $1000 \pm 51 \%$ \\
& & P2-P5 & $0.073 \pm 9 \%$ & $1000 \pm 50 \%$ \\
& & P3-P4 & $0.039 \pm 36 \%$ & $500 \pm 77 \%$ \\
& & P3-P5 & $0.055 \pm 28 \%$ & $700 \pm 69 \%$ \\
& & P4-P5 & $0.074 \pm 49 \%$ & $1000 \pm 90 \%$ \\
\hline Understory 5 & $0.90 \pm 9 \%$ & P3-P4 & $0.088 \pm 28 \%$ & $1500 \pm 37 \%$ \\
& & P3-P5 & $0.164 \pm 7 \%$ & $2800 \pm 16 \%$ \\
\hline Understory & $1.32 \pm 8 \%$ & P4-P5 & $0.245 \pm 9 \%$ & $4100 \pm 18 \%$ \\
11 & & P4-P5 & $0.245 \pm 9 \%$ & $6000 \pm 17 \%$ \\
& & P4-P6 & $0.222 \pm 3 \%$ & $5500 \pm 11 \%$ \\
& & P5-P6 & $0.191 \pm 7 \%$ & $4700 \pm 15 \%$ \\
\hline Understory 1 & $1.03 \pm 6 \%$ & P3-P4 & $0.166 \pm 15 \%$ & $3200 \pm 21 \%$ \\
& & P3-P5 & $0.178 \pm 16 \%$ & $3400 \pm 22 \%$ \\
& & P4-P5 & $0.177 \pm 10 \%$ & $3400 \pm 16 \%$
\end{tabular}


Of particular note is a region of slow spread between P3 and P4. There was a deceleration of the fire here, with a $41 \%$ reduction in mean spread rate from $\mathrm{P} 2$ to $\mathrm{P} 3$. The spread increased again from $\mathrm{P} 4$ to P5, though increased heterogeneity is observed ( $\pm 49 \%$ deviation) which is likely due to gaps in fuel loading. The deceleration and acceleration is believed to be partially a result of ambient wind, and will be discussed later.

The Understory 5 and 11 locations are considered together, as they are roughly in line with each other in the direction of fire spread. Surface fireline intensities are considerably higher in this region, ranging from $1500-6000 \mathrm{~kW} \cdot \mathrm{m}^{-1}$. Here again, a slowing of the fire occurred between P3 and P4. Although the placement of mass consumption measurements does not allow for an accurate measure of intensity from $\mathrm{P} 2$ to $\mathrm{P} 3$ in this part of the block, the mean spread is between P3 and P4 is a $26 \%$ reduction from the P2 to P3 value $\left(0.119 \mathrm{~m} \cdot \mathrm{s}^{-1}\right)$. There is an increase of fire intensity moving from P3 to P5, with both higher spread rate and higher mass consumption measured at Understory 11 . Indeed, of all regions examined in this study, both quantities are at a maximum in this location. Between P5 and P6 there is another slight reduction in spread.

To give a qualitative indication of the type of fire being measured, Figure 3a shows a frame of video footage. The camera was directed towards Understory 11, though it shows fire behaviour closer to the perimeter of the parcel. This region predominantly experienced a surface fire with localized torching into the tree crowns. Fire spread, however, was not supported continuously from crown to crown. Instead, vertical flame spread up the tree trunks resulted in brief periods of crown fuel consumption for individual trees.

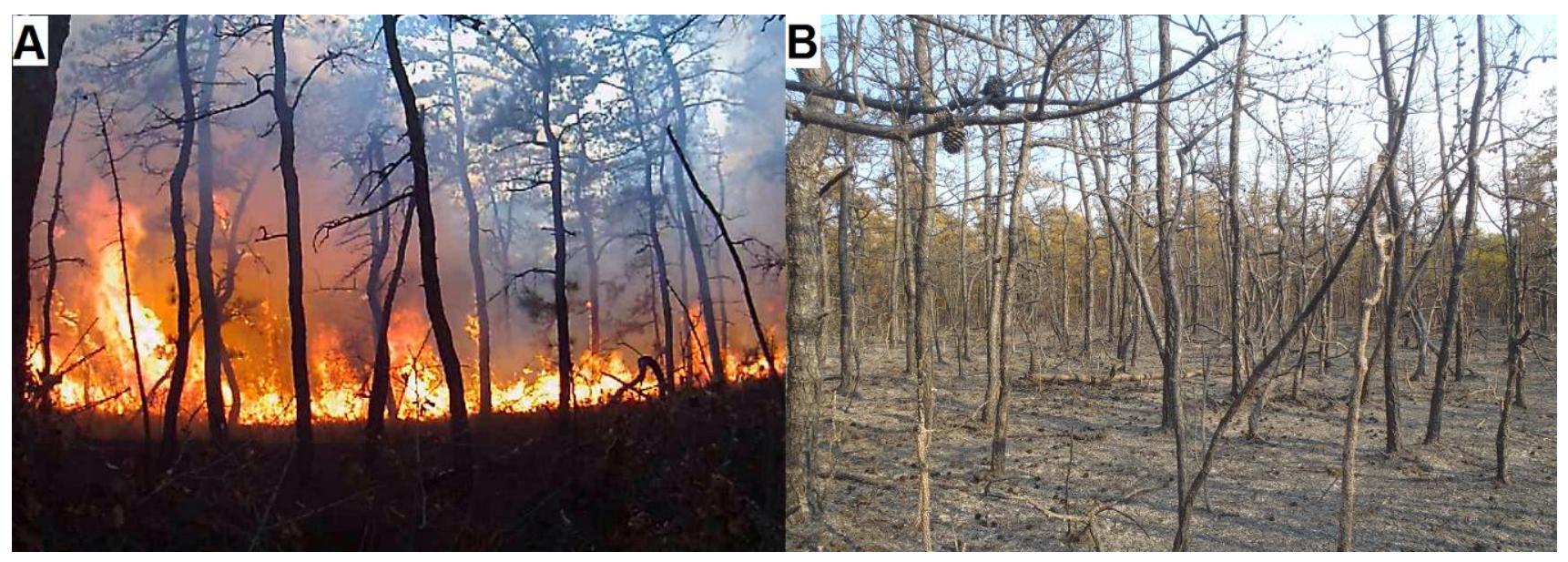

Figure 3. Examples of visual data. (a) Image from camera facing east towards Understory 11 (distortion is due to the wide angle lens used), and (b) image of post-fire fuel consumption in the vicinity of Understory 1.

Understory 1 experienced surface fireline intensities in the range of $3200-3400 \mathrm{~kW} \cdot \mathrm{m}^{-1}$, which fall between the values at Understory 10 and those at Understory 5 and 11. This region exhibited the most consistent fire behavior, with no obvious accelerations or decelerations. Additionally, observations of significant crown involvement were reported in this area, particularly near P3, close to the ignition line. This is confirmed by post-fire photographs of the region, where very little crown vegetation remains compared to other sections of the burn block (e.g. Figure 3b). However, the location described was to the northwest of Understory 1, beyond the measurements of surface fuel consumption, so the behavior pictured is not well reflected in the values of Table 2 .

\subsection{Wind}

Wind is a critical factor to consider when analyzing the behavior of any wildfire. In the case of this experiment, the focus was first directed to the ambient winds measured by the sonic anemometer on the Overstory Control tower to the west. The magnitude of the horizontal winds at this location is 
shown in Figure 4a. The curve was obtained by applying a loess-type moving average filter to the instantaneous values, in order to show the dominant wind gusts more clearly. Over the interval plotted, the average unfiltered horizontal wind is $1.8 \mathrm{~m} \cdot \mathrm{s}^{-1}$, with a peak magnitude of $6.4 \mathrm{~m} \cdot \mathrm{s}^{-1}$. Table 3 shows the mean horizontal wind magnitude at the Overstory Control tower for different intervals of fire spread. The instantaneous horizontal wind direction measured at the Overstory Control tower is shown in Figure 4b. Points where horizontal wind magnitude is less than $0.5 \mathrm{~m} \cdot \mathrm{s}^{-1}$ have been omitted from this figure, as low winds are more susceptible to rapid fluctuations in direction, which do not represent the dominant wind direction and make the data more difficult to interpret.
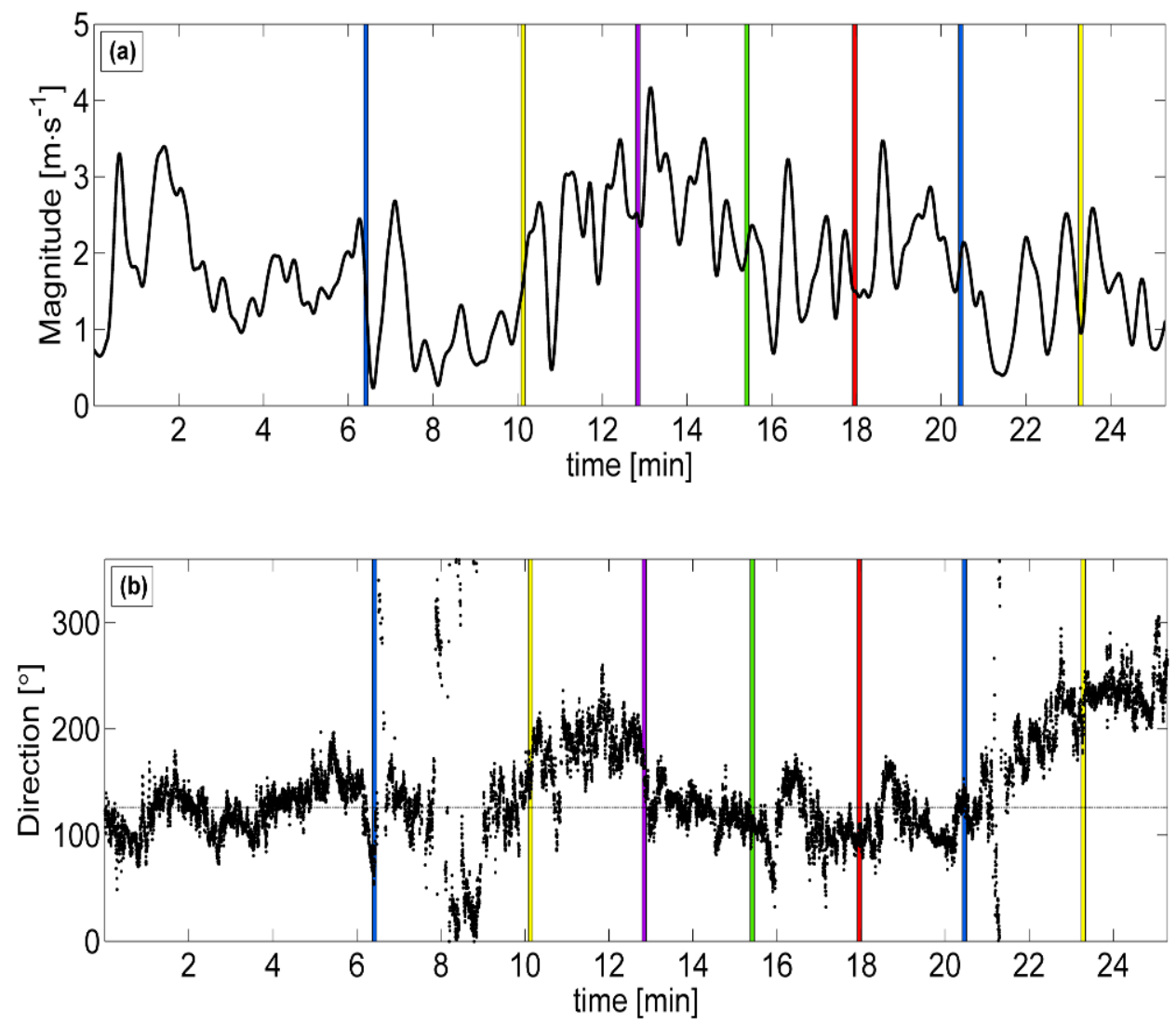

Figure 4. (a) Magnitude and (b) direction of horizontal winds at the sonic anemometer on the Overstory Control tower. Colored lines correspond to the time of fire contours P2-P8 (refer to Figure 2). Time is given in minutes from the start of ignition. Direction is given in compass degrees (clockwise from north). The horizontal line in figure (b) represents the general direction of fire spread.

From this information it can be seen that, as the fire built from ignition, winds were coherent to the direction of initial fire spread (estimated from fire contours as roughly $125^{\circ}$ ). Between P2 and P3, the wind is reduced somewhat and this corresponds to a shift in direction. From P3 to P4, where a reduction in fire spread was noted at the northeastern section of the burn block, the wind does pick up again, but the direction is oblique to fire spread by about $60^{\circ}$. From P4 to P5, where fire spread was high across the entire block, ambient wind is both relatively strong and consistent with fire spread. It is during this interval that the peak value of $6.4 \mathrm{~m} \cdot \mathrm{s}^{-1}$ was measured. This wind direction persists until around $\mathrm{P} 7$, where a shift is again observed. 
Table 3. Mean horizontal magnitude of winds at the sonic anemometers (height of $12.5 \mathrm{~m}$ ) on the Overstory Control and Overstory West towers.

\begin{tabular}{ccc} 
Interval & $\begin{array}{c}\text { Control Magnitude } \\
{\left[\mathrm{m} \cdot \mathrm{s}^{-1}\right]}\end{array}$ & $\begin{array}{c}\text { West Magnitude } \\
{\left[\mathrm{m} \cdot \mathrm{s}^{-1}\right]}\end{array}$ \\
\hline Ignition - P2 & 1.8 & 1.6 \\
P2 - P3 & 1.0 & 2.3 \\
P3 - P4 & 2.4 & 2.2 \\
P4 - P5 & 2.7 & 3.0 \\
P5 - P6 & 1.8 & 3.3 \\
P6 - P7 & 2.1 & 2.5 \\
P7 - P8 & 1.4 & 2.4
\end{tabular}

To understand the local influence of the fire on wind conditions within the study site, a comparison is made to the instantaneous horizontal wind direction measured at the Overstory West tower. This data is shown in Figure 5 (with low-velocity data omitted, following the previous convention). Mean horizontal magnitudes are also summarized in Table 3. Deviations from measurements at the Overstory Control tower appear to be fire induced and result from combination of low ambient winds and strong fire behavior. From the ignition to $\mathrm{P} 2$, a period of relatively weak ambient wind corresponds with a swing in local wind direction towards the north, where the fire has already established. A similar shift is observed as the fire reaches P3, with even lower ambient winds. From P3 to P4, as the ambient wind shifts to the south, the local wind has more of a westerly direction. This is likely caused by entrainment to the fire plume, which at this point is approaching the Overstory West tower from the northwest. Between P4 and P5, the dominant direction follows the ambient, but the scatter in this data is much greater. This is due to the fact that the anemometer has now started to be impacted by the turbulent plume. Data during this period should be treated with some caution, as the temperature rating of the device only extends to $50{ }^{\circ} \mathrm{C}$. Following the pass of the fire front at P5, the local winds align with the direction of fire spread for the rest of the time shown. The direction is also roughly in line with ambient winds, but the higher magnitude locally suggests there is still an influence of entrainment to the plume.

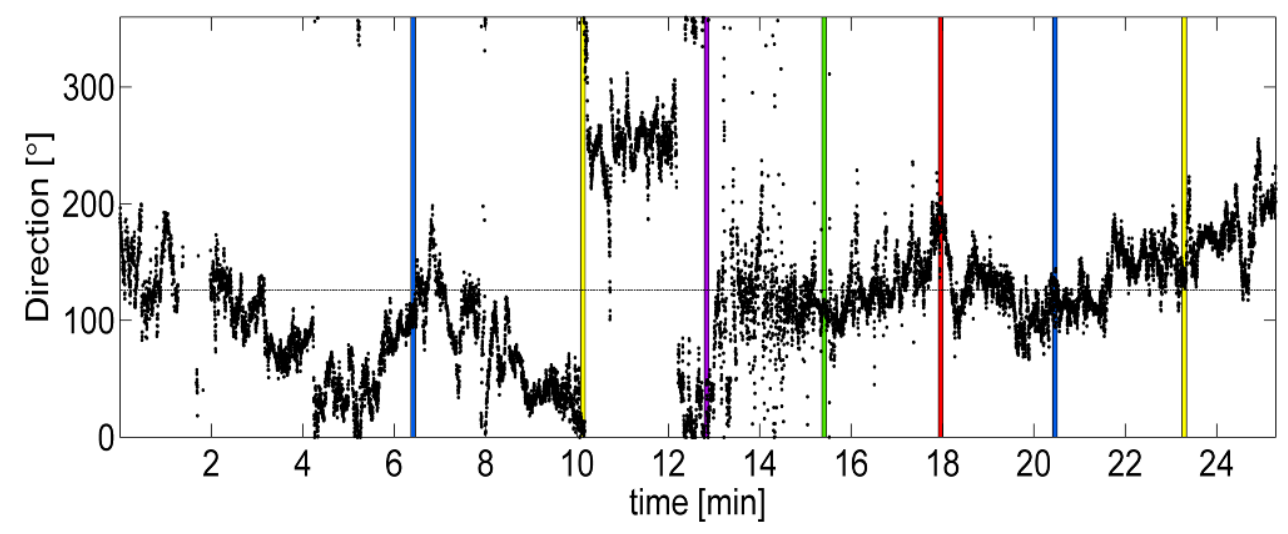

Figure 5. Direction of horizontal winds at the sonic anemometer on the Overstory West tower. Colored lines correspond to the time of fire contours P2-P8 (refer to Figure 2). Time is given in minutes from the start of ignition. Direction is given in compass degrees (clockwise from north). The horizontal line represents the general direction of fire spread.

\subsection{Canopy consumption}

An examination of canopy fuel consumption is also very important to assessing fire behavior. Although the LiDAR data cannot yet be used to obtain direct measures of mass consumption, a 
qualitative analysis of the data can still provide valuable information. The percent difference in the pre- and post-fire data was obtained over the $10 \mathrm{~m}$ x $10 \mathrm{~m} \times 1 \mathrm{~m}$ measurement grid. Transects of this data, which follow the direction of fire spread and pass through grid cells containing understory towers of interest, are shown in Figure 6. Note that because the transects are at an angle to the rectilinear LiDAR grid, the cells shown in Figure 6 have a horizontal extent greater than $10 \mathrm{~m}$.

A comparison of the transects reveals that the Understory 10 and 5 had relatively little canopy fuel consumption, corresponding to the lower surface fireline intensities. In both cases, as the fire reached roughly 40-60 $\mathrm{m}$ from the ignition line, a transition to canopy fuel consumption occurred. This type of canopy fuel involvement continued as the fire spread from Understory 5 to Understory 11 . The transect for Understory 1 shows somewhat different fire behavior. Canopy fuel is quickly involved in the fire, with this initial region corresponding to the area photographed in Figure 3b. This type of behavior appears to persist along the distance shown, with some small variability, such as a drop in consumption around $40 \mathrm{~m}$.
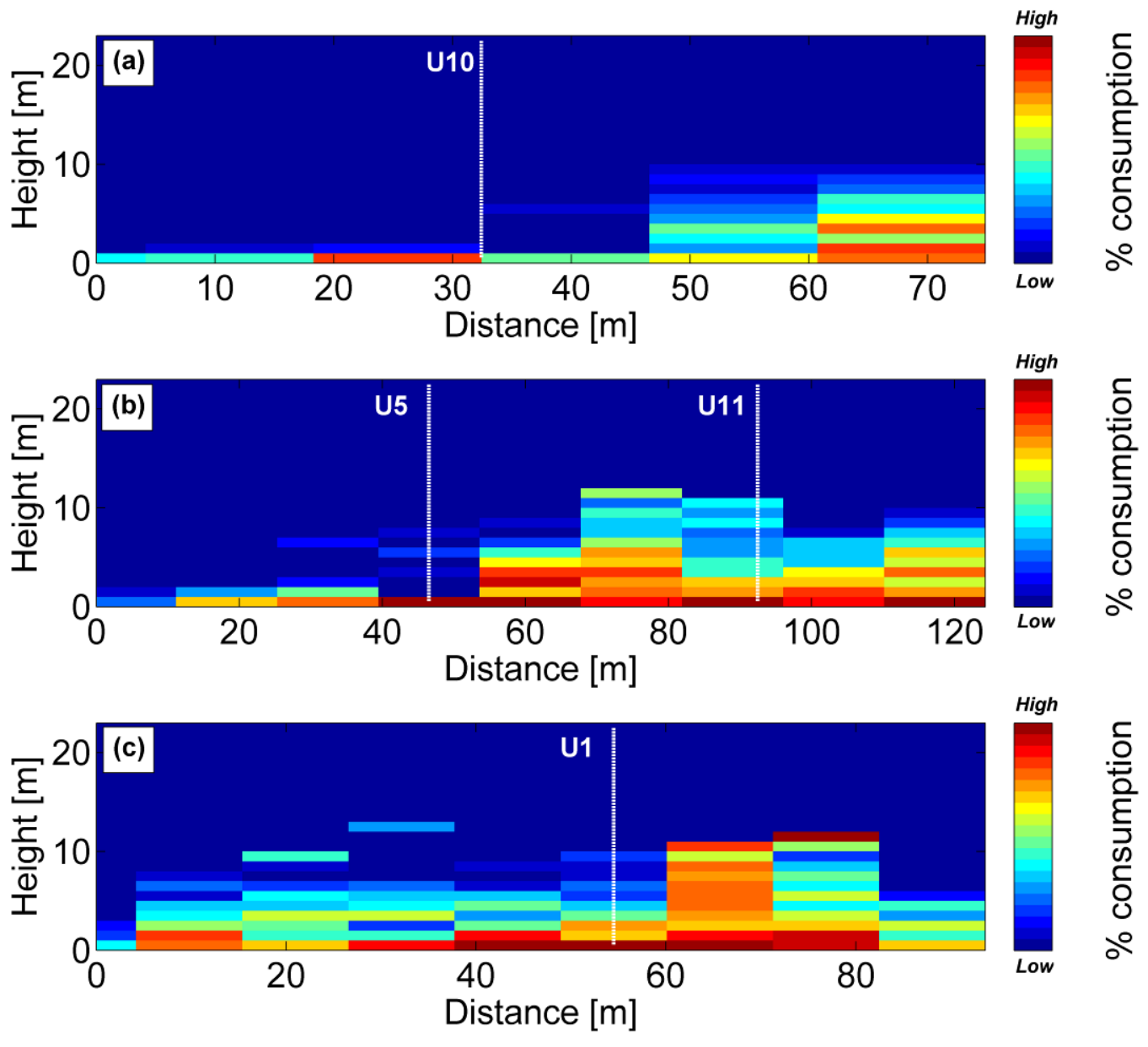

Figure 6. Percent canopy consumption estimated from uncalibrated LiDAR data. Transects are shown in the direction of fire spread for (a) Plot 10, (b) Plot 5 and 11, and (c) Plot 1. Distance is given in meters from the ignition line.

\section{Discussion}

The features of fire spread examined in this initial study help quantify the type of fire which was observed. Surface fireline intensities, which range from $500-6000 \mathrm{~kW} \cdot \mathrm{m}^{-1}$, can be compared to other fires, such as those summarized in Morandini and Silvani (2010). Spread rates reported for several shrubland fires fall within the range of $0.003-0.4 \mathrm{~m} \cdot \mathrm{s}^{-1}$, which is comparable to those determined here. 
However, for the shrubland fire intensities presented by Morandini and Silvani (2010) the upper range was $48000 \mathrm{~kW} \cdot \mathrm{m}^{-1}$. Wind speed in these studies was within the range of $0-7.9 \mathrm{~m} \cdot \mathrm{s}^{-1}$, which is again comparable. It should be noted that the measurements discussed from this experiment were made above the canopy, and the drag of the canopy vegetation will cause lower values at the level of the shrubs. The considerably higher intensities can be traced back to the fuel loading. As expected, shrub layers in the open environments of the report tended to be denser than the shrub layer of a forested environment, such as the PNR. Values as high as $25 \mathrm{~kg} \cdot \mathrm{m}^{-2}$ were found in these previous experiments. Therefore, a prescribed fire which consumes a significant percentage of the shrub layer will be less intense in the environment studied here. However, in the case of this experiment, surface fuels are not the only contributors, and, when considering total fireline intensity, the inclusion of canopy fuel consumption will play a significant role in some areas.

In order to complete this investigation, a full study of canopy fuel structure and consumption will be critical. The different regimes discussed previously in Figure 6 are of particular interest. The transition from surface fire to canopy fuel involvement near Understory 5 is reflected in the fact that surface fireline intensity nearly tripled as the fire passed through this region (see Table 2). However, such a transition is not obvious in the surface fireline intensities near Understory 10 . This can be attributed to the fact that the physical fuel samples at this location were taken in the region before the transition. At Understory 1 the more consistent canopy consumption can be seen in the low variation of surface fireline intensity. Examination of the pre-fire canopy arrangement will help provide insight into the presence of transitions. It may be that spatial features of the fuel density played as much or more of a role than wind in causing changes in local fire behavior.

Mean wind speed in this experiment was relatively low compared to what might be considered severe wildland fire conditions. For example, during a famously catastrophic fire in the PNR in 1963, peak wind gusts exceeding $22 \mathrm{~m} \cdot \mathrm{s}^{-1}$ were measured (Hughes 1987). Despite this, it appears that shifts in wind direction and magnitude may have affected certain observed aspects of fire behavior. One example is the reduction and then increase in fire spread which was observed between P3 and P5, towards the northeast corner of the block. This corresponded with a roughly $60^{\circ}$ swing in wind direction. As discussed previously, the fire here did not have significant canopy fuel involvement. Therefore, it is likely that the less intense fire was susceptible to the influence of ambient wind. Conversely, fire spread was quite consistent in the region of Understory 1 during this time. The fire near Understory 1 should be less influenced by ambient winds, however, due to the stronger convective plume where canopy fuels are invloved. The ongoing study of the impact of wind on fire behavior must take into account the fact that measurements shown were taken at $12.5 \mathrm{~m}$, and not within the understory. However, with the largely even topography and fuel loading, shifts above the canopy should correspond to shifts in the lower winds at the level of the shrub layer.

Many other aspects remain to be studied as well. Measurements of upward radiant flux, vertical velocity, and turbulent statistics at understory tower locations will supplement the comparison of variations in fire behavior throughout the burn block. Continued analysis of video footage will also help in interpreting the LiDAR data. The regions in which canopy fuels were involved in fire spread are clearly seen in the Figure 6 . However, whether this represents localized torching supported by the surface fire, as shown in Figure 3a, or if true continuous crown fire spread was experienced in some locations, requires further investigation.

\section{Conclusions}

This work represents an initial effort to understand the behavior of an experimental fire and the fire spread dynamics. A time series of aerial IR imagery, destructive field sampling of fuel loading and consumption, as well as wind measurements were analyzed, along with a preliminary qualitative discussion of LiDAR data. Several features of fire behavior were identified: 
- Observations revealed a predominantly surface fire, with localized torching of tree crowns.

- The involvement of canopy fuels in fire spread was identified with LiDAR measurements, and a clear transition from a pure surface fire was revealed in some locations.

- Ambient winds were relatively low. Wind is believed to have influenced low-intensity surface fire spread, and to have played a role in the aforementioned transition, but had little impact on more intense fire behavior.

- As the fire grew, local winds within the study site appeared to be dominated by fire induced flow, both preceding and following the passage of the fire front.

This analysis will expand, as additional measurements are integrated to provide a more complete description of the behavior. However, the results presented in this investigation give a qualitative baseline and a first understanding of the dynamics of the fire spread. Once coupled with total fuel consumption across the entire burn block, an assessment of the level of fuel reduction, given this type of fire, can be made. In addition, fire contours, spread rates, surface fuel consumption, and wind measurements will all become comparison points for future efforts to model this fire.

\section{Acknowledgements}

The authors wish to thank the Joint Fire Science Program (JFSP) for funding this research effort (project \#12-1-03-11). Dr. Filkov was supported by the Tomsk State University Competitiveness Improvement Program and the Russian Foundation for Basic Research (project number 14-01-00211a). The authors would also like to thank the NJFFS for their cooperation in the planning and execution of the experimental fires, as this was critical to the success of the project.

\section{References}

Alexander, ME (1982) Calculating and interpreting forest fire intensities. Canadian Journal of Botany 60(4), 349-357.

Butler BW, Jimenez D, Forthofer J, Shannon K, Sopko P (2010) A portable system for characterizing wildland fire behavior. In VI International Conference on Forest Fire Research. D.X. Viegas (Ed.). Coimbra, Portugal, November, 2010.

Byram GM (1959) Combustion of forest fuels. In 'Forest fire: Control and use'. (Ed. KP Davis) pp.6189, 554-555. (McGraw-Hill: New York)

Clark, KL, Skowronski NS, Gallagher M, Carlo N, Farrell M, Maghirang, MR (2013) Assessment of Canopy Fuel Loading Across a Heterogeneous Landscape Using LiDAR. USDI Joint Fire Science Program, Project \#10-01-02-14, Final Report, 47pp.

Frankman David, Webb Brent W., Butler Bret W., Jimenez Daniel, Forthofer Jason M., Sopko Paul, Shannon Kyle S., Hiers J. Kevin, Ottmar Roger D. (2013) Measurements of convective and radiative heating in wildland fires. International Journal of Wildland Fire 22(2), 157-167.

Gorte, RW (2011) Federal funding for wildfire control and management. Congressional Research Service: 7-5700, 29pp.

Hughes, J. (1987) New Jersey, April 1963: can it happen again?. Fire Management Notes 48(1): 3-6.

McKeown D, Faulring J, Krzaczek R, Cavilia S, van Aardt J (2011) Demonstration of delivery of orthoimagery in real time for local emergency response. SPIE Defense, Security, and Sensing, International Society for Optics and Photonics.

Morandini F, Silvani X (2010) Experimental investigation of the physical mechanisms governing the spread of wildfires. International Journal of Wildland Fire 19(5): 570-582. 
Omi, PN, Martinson, EJ (2002) Effect of fuels treatment on wildfire severity. Final report submitted to the Joint Fire Science Program Governing Board for Project Number 99-1-4-01. Colorado State University, Fort Collins, CO.

Santoni PA, Simeoni A, Rossi JL, Bosseur F, Morandini F, Silvani X, Balbi JH, Cancellieri D, Rossi L (2006) Instrumentation of wildland fire: characterisation of a fire spreading through a Mediterranean shrub. Fire Safety Journal 41(3): 171-184.

Skowronski NS, Clark KL, Duveneck M, Hom J (2011) Three-dimensional canopy fuel loading predicted using upward and downward sensing LiDAR systems. Remote Sensing of Environment 115(2): 703-714.

Van Wagner, CE (1972) Heat of combustion, heat yield, and fire behaviour. Canadian Forest Service, Petawawa Forest Experiment Station, Information Report PS-X-35. (Chalk River, ON) 